\title{
Selection of sorghum hybrids grown under aluminum saturation
}

\author{
C.B. Menezes ${ }^{1}$, G.A. Carvalho Junior ${ }^{2}$, L.A. Silva ${ }^{3}$, K.C. Bernardino ${ }^{1}$, \\ J.V. Magalhães ${ }^{4}$, C.T. Guimarães ${ }^{4}$, L.J.M. Guimarães ${ }^{1}$ and R.E. Schaffert $^{1}$ \\ ${ }^{1}$ Núcleo de Recursos Genéticos e Desenvolvimento de Cultivares, \\ Embrapa Milho e Sorgo, Sete Lagoas, MG, Brasil \\ ${ }^{2}$ Department of Soil and Crop Sciences, Texas A\&M University, \\ College Station, TX, USA \\ ${ }^{3}$ Genética e Melhoramento de Plantas, Universidade Federal do Acre, \\ Cruzeiro do Sul, AC, Brasil \\ ${ }^{4}$ Núcleo de Biologia Aplicada, Embrapa Milho e Sorgo, \\ Sete Lagoas, MG, Brasil \\ Corresponding author: C.B. Menezes \\ E-mail: cicero.menezes@embrapa.br \\ Genet. Mol. Res. 13 (3): 5964-5973 (2014) \\ Received June 17, 2013 \\ Accepted December 18, 2013 \\ Published August 7, 2014 \\ DOI http://dx.doi.org/10.4238/2014.August.7.12
}

ABSTRACT. The purpose of this study was to evaluate 165 hybrids
derived from lines previously selected for aluminum (Al) tolerance.
Nine check cultivars were used, eight commercial hybrids and one
experimental hybrid. Hybrids were evaluated at three levels of Al
saturation $(0,20$ and $40 \%$ on average). The differences between the
environments were significant. Environment with $0 \% \mathrm{Al}$ saturation
yielded $29.5 \%$ more than that with $40 \% \mathrm{Al}$ saturation, showing the
importance of genotype selection for acid soils. The best check
cultivar was the hybrid DKB550. The hybrids AG1020 and AG1040
also performed well, where the latter was more tolerant but the former
more responsive to environment improvement. The hybrid BRS304
was susceptible to high levels of Al saturation. The three commercial
BRS hybrids (BRS310, BRS330 and BRS332) performed better than 
BRS304 at high Al saturation. The hybrid BRS330 was the best BRS hybrid to grow on a field with high Al saturation. The hybrid DKB559 performed well at high $\mathrm{Al}$ saturation but did not respond to environment improvement. The hybrids 727029, 727039, 729041, 729095, 729109, AG1040, and DKB550 were tolerant to higher levels of Al saturation and responsive to environment improvement, and showed good stability and adaptability at both low and high $\mathrm{Al}$ saturation.

Key words: Sorghum bicolor; Grain sorghum; Soil acidity; Hybrid selection

\section{INTRODUCTION}

Sorghum [Sorghum bicolor (L.) Moench] is the fifth most important cereal grown in the world, surpassed only by wheat, rice, maize, and barley. It has adaptive characteristics for growing in marginal areas far more than these other cereals. Sorghum is grown on 40 million hectares in 105 countries in Africa, Asia, Oceania and Americas. World sorghum production during 2010 was about 56 million tons of grain from 41 million hectares with an average productivity of 1.4 t/ha, with the United States, India, Mexico, Nigeria, Sudan, Ethiopia, Australia, and Brazil being major producing countries, in the cited order (FAO, 2011).

In Brazil, the acreage of grain sorghum showed significant expansion in recent years, reaching in 2011/2012 an area of 800 thousand hectares, with an average yield of $2800 \mathrm{~kg} / \mathrm{ha}$ (APPS; Associação Paulista dos Produtores de Sementes e Mudas, 2012). This expansion was primarily due to the increase in per capita consumption of animal protein and the development of new hybrids adapted to the cropping system.

The Central-West and Southeast regions account for over $80 \%$ of the national production of sorghum, yet the South and Northeast have also shown investments in research and dissemination of the crop (Agrianual, 2011). As Brazil is very diverse in terms of climatic conditions, the performance of sorghum hybrids is not equivalent in all regions. In the South, sorghum is sown in spring and harvested in autumn. In central Brazil, sowing is done in succession to summer crops, especially soybeans. In the Northeast, the crop is planted in the rainy season. A common feature of all these areas of cultivation is rainfed planting.

One-third of the cultivated area in Brazil is formed by the Cerrado ecosystem, where a great part of the agricultural production occurs on highly acid soil. The low $\mathrm{pH}$ contributes to solubilize aluminum ( $\mathrm{Al})$ and makes it available in the soil for plant assimilation, causing severe damage to non-adapted genotypes. The main effect is a slow growth of the root system resulting in the development of surface roots. This hampers the use of soil nutrients and makes plants more drought susceptible (Foy et al., 1993; Hartwig et al., 2007; Inostroza-Blancheteau et al., 2008).

Soil acidity is a major issue in agriculture throughout the world, and an estimated $50 \%$ of the world's arable land is acidic (Kochian et al., 2004). These soils are characterized by high-base cation leaching capacity, low-base saturation and low availability of phosphorus (Ryan et al., 2011). The most prominent symptom of Al toxicity is the inhibition of root growth, which leads to nutrient deficiencies and water stress (Kochian et al., 2004).

The limitation for crop production in acid soils could be overcome either by the addition of chemical amendments such as lime and fertilizers or by the use of species or cultivars 
that can tolerate soil acidity constraints. The second approach has a practical application in many parts of the world, since chemical amendments are costly inputs for many farmers. The identification of cultivars that can tolerate soil acidity limitations is needed and these superior acid-tolerant cultivars will assist not only in increasing the area under sorghum production, but also in enhancing yield per unit area. Acid-tolerant genotypes will aid breeders in producing superior cultivars that not only have adaptability to acid soils but will also have high-yield potentials. Soil and solution culture methods have clearly shown the existence of a range of $\mathrm{Al}$ stress tolerance in sorghum.

The genetic variability between genotypes or cultivars within the same species exists for tolerance to aluminum toxicity. Natural genetic variation for aluminum tolerance in crops is well documented. The existence of aluminum-tolerant plants and differences in aluminum tolerance between genotypes indicate that tolerance to aluminum toxicity is genetically controlled. Genetic variability between species and within species has been noted in crops such as tomato, wheat, barley, maize, rice, soybean, pea, cabbage, chickpea, okra, etc. (Ryan et al., 2011). Genetic variability of these crops can be exploited to develop aluminum-tolerant cultivars and to explore the number of genes involved in aluminum tolerance.

The purpose of this study was to evaluate the effect of high Al saturation on grain sorghum yield grown in the field. Relative yield values were determined to quantify the effect of high Al saturation on grain sorghum yield.

\section{MATERIAL AND METHODS}

Fifty-five sterile male lines and three restorer lines, previously selected for tolerance to aluminum, were crossed in a diallel system by controlled hand pollination. The diallel hybrids were made in 2007 and evaluated in 2008. The resulting 165 hybrids and 9 check cultivars were grown in a field with three different levels of Al saturation $(0,20$ and $40 \%$ on average). Among the check cultivars, there were two hybrids known to be susceptible to high Al saturation (BRS304 and BRS332) and two known tolerant ones (BRS310 and BRS330).

Tolerance to Al present in female lines was derived from the line SC283, which possesses the Al-tolerance gene, $A l t_{S B}$ (Magalhaes et al., 2004). All female lines share some similarity, since all of them were twice backcrossed to ATF54B. The Al tolerance of the three male lines came from the accession CMSXS225 or SC549. Hybrids 727 came from male line BR12RxSC549, while 728 came from line BR12RxCMSXS225-1 and 729 came from BR12RxCMSXS225-2. These sources of Al tolerance were previously selected in nutrient solution by Caniato et al. (2007). The two male sources of Al tolerance were crossed and backcrossed $\left(\mathrm{BC}_{6}\right)$ to $\mathrm{BR} 012 \mathrm{R}$.

The sorghum hybrids were grown in an incomplete block design with three replications. Plots consisted of 1 row, $5 \mathrm{~m}$ long, with $0.45 \mathrm{~m}$ between rows. Plots were thinned to 12 cm between plants $(180,000$ plants/ha).

The trials were carried out at the aluminum-phenotyping site at Embrapa Maize and Sorghum, in Sete Lagoas, MG, Brazil. Sete Lagoas is located at $767 \mathrm{~m}$ above sea level and receives an average annual rainfall of $1400 \mathrm{~mm}$; the temperature ranges from $17^{\circ}$ to $25^{\circ} \mathrm{C}$.

Various levels of dolomite limestone with $33 \% \mathrm{CaO}$ and $14 \% \mathrm{MgO}$ were broadcasted over the entire area and disked to a depth of $20 \mathrm{~cm}$ to achieve exchangeable Al saturation of 0 and $20 \%$. No limestone was needed in the area with $40 \% \mathrm{Al}$ saturation. Starter fertilizers were 
applied using formulated fertilizer 08-28-16 (N-P-K) + Zn. All three areas received $350 \mathrm{~kg} / \mathrm{ha}$ 08-28-16 (N-P-K) + Zn. At the sixth-leaf stage, $250 \mathrm{~kg} / \mathrm{ha}$ urea was side dressed in the area with 0 and $20 \% \mathrm{Al}$ saturation, and $400 \mathrm{~kg} / \mathrm{ha}$ ammonium sulfate in the area with $40 \% \mathrm{Al}$ saturation.

Weeds were controlled with atrazine (2-chloro-4-ethylamine-6-isopropylamine-s-triazine) at $3.0 \mathrm{~kg} / \mathrm{ha}$, and hand hoeing was used as needed to control additional weeds during the study.

All panicles from each plot were harvested by threshing and air-dried for at least 7 days to determine grain yield, after correction for $13 \%$ moisture. Data about plant height, days to $50 \%$ bloom and harvest index (ratio of grain yield to panicle weight) were also taken.

Statistical analyses were performed considering mixed models via REML/BLUP, using model 52 of the SELEGEN-REML/BLUP software, proposed by Resende (2007b), which is appropriate for analysis of trials in incomplete block designs performed in different environments, and provided predicted values for adaptability and stability measurement MHPRVG, according to the following model:

$$
\mathrm{y}=\mathrm{Xr}+\mathrm{Zg}+\mathrm{Wb}+\mathrm{Ti}+\mathrm{e},
$$

(Equation 1)

where $y$ is the observations of the evaluated characteristic vector; $r$ is the replication effect vector (assumed as fixed) added to the general mean; $g$ is the genotypic effect vector (assumed as random); $b$ is the block effect vector (assumed as random); $i$ is interaction effects of genotype $\mathrm{x}$ environment vector (considered random); $e$ is the error vector also considered random. $\mathrm{X}$ is the incidence matrix for replication effects; $\mathrm{Z}$ is the incidence matrix for genotypic effects; $\mathrm{W}$ represents the incidence matrix for block effects; $\mathrm{T}$ is the incidence matrix for interaction genotype $\mathrm{x}$ environmental effects.

\section{RESULTS AND DISCUSSION}

Table 1 presents the estimates of the components of genetic and phenotypic variances for grain yield, considering all environments. The heritability for this trait was high (0.80), where it can be inferred that genetic progress is feasible and could help breeding programs to adapt sorghum to Al-stressed soils, with the selection of the best lines of these hybrids. Caniato et al. (2007), using a global, SSR-based, genetic diversity analysis in a broader sorghum set, revealed the presence of both multiple $A t_{S B}$ alleles and different Al-tolerance genes within highly related accessions. This diversity and possible high heritability suggest that improvements in aluminum tolerance in sorghum are effective using traditional mass selection breeding techniques. It can be inferred that the experimental precision in the combined analyses was intermediate, as indicated by the estimate of experimental variation $(\mathrm{CVe}(\%)=24.35)$ (Table 1). The estimate of accuracy, which measures the correlation between predicted and true values, was high (90\%). According to Resende (2007a), the accuracy in breeding programs should be higher than $70 \%$, and above $90 \%$ of the experimental precision can be considered excellent.

The overall mean grain yield, considering the three environments, was $5.15 \mathrm{t} / \mathrm{ha}$, which is 2 -fold the Brazilian yield of $2.4 \mathrm{t} / \mathrm{ha}$. The results indicate that $\mathrm{Al}$ saturation has a significant effect on hybrid performance in the field (Figure 1). At 0, 20 and $40 \%$ soil Al saturation, the hybrids yielded 6.04, 5.16 and $4.25 \mathrm{t} / \mathrm{ha}$, respectively. Compared to low Al saturation ( $0 \%)$, the hybrid yields decreased 14.5 and $29.5 \%$ at 20 and $40 \% \mathrm{Al}$ saturation, respectively. These data show that $\mathrm{Al}$ saturation is very important in the soil and can reduce yield significantly. 
The primary response to aluminum stress occurs in the roots. Aluminum toxicity causes yield reduction in sorghum, because it inhibits root growth, having a direct effect on the ability of a plant to absorb water and nutrients (Baligar et al., 1989).

Table 1. Variance components, accuracies, genotypic and residual coefficient of variation considering 165 sorghum hybrids grown in three different Al saturation environments for grain yield in the field (Sete Lagoas, 2008).

\begin{tabular}{|c|c|c|c|}
\hline Effects & Deviance & LRT (chi-square) & Variance components \\
\hline Complete model & 1875.17 & - & - \\
\hline Genotypic & 1941.34 & $66.17 * *$ & $0.37 * *$ \\
\hline Blocks & 1884.09 & $8.92 * *$ & $0.06^{* *}$ \\
\hline Genotype $\mathrm{x}$ environment interaction & 1875.19 & $0.02^{\mathrm{ns}}$ & $0.01^{\mathrm{ns}}$ \\
\hline Residual & - & - & 1.54 \\
\hline h²mg (adjusted heritability) & 0.80 & & \\
\hline Acgen (accuracy of genotypes) & 0.90 & & \\
\hline CVg (\%) & 11.88 & & \\
\hline CVe (\%) & 24.35 & & \\
\hline General mean & 5.15 & & \\
\hline
\end{tabular}

Table chi-square, with 1 degree of freedom: $6.63(1 \%)$ and $3.84(5 \%) . * *$ Significance at $1 \%$ according to the chisquare test with 1 degree of freedom; ns = non-significant difference. $\mathrm{LRT}=$ maximum likelihood ratio test.

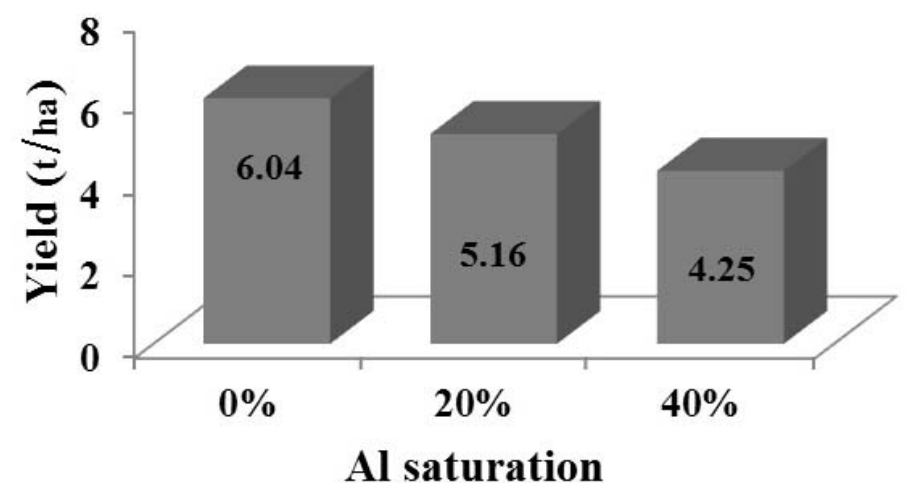

Figure 1. Means for sorghum grain yield of 174 hybrids at three levels of soil Al saturation.

Plant height, days to $50 \%$ bloom and harvest index were not affected by $\mathrm{Al}$ stress. The target of $\mathrm{Al}$ toxicity is the root tip, in which $\mathrm{Al}$ exposure causes inhibition of cell elongation and cell division, leading to root stunting accompanied by reduced water and nutrient uptake (Samac and Tesfaye, 2003).

Flores et al. (1988) conducted an experiment to determine the variation in sorghum growth and yield associated with Al saturation of the soil. They studied both susceptible and tolerant genotypes of grain sorghum grown at both $40 \%(\mathrm{pH} 4.6)$ and $60 \%(\mathrm{pH} 4.1) \mathrm{Al}$ saturation. The study determined that the acid-tolerant genotypes grown at $60 \% \mathrm{Al}$ saturation had lower root mass scores and delayed flowering. However, differences in yield and growth traits for the acidtolerant genotypes grown at 40 or $60 \% \mathrm{Al}$ saturation were not found. The susceptible genotypes showed an improvement in yield and growth traits at lower Al saturation compared to higher $\mathrm{Al}$ saturation. All sorghum genotypes grown at above $70 \% \mathrm{Al}$ saturation performed poorly. 
Baligar et al. (1989) found that grain yields were reduced by an average of $24 \%$ at $41 \% \mathrm{Al}$ saturation as compared to $2 \% \mathrm{Al}$ saturation; however, at $64 \% \mathrm{Al}$ saturation the reduction was $54 \%$. In this study, the genotype $\mathrm{x}$ environment interaction was significant and the genotype IS3911C had the highest grain yield at $41 \%$ Al saturation; however, genotype CMSXS604 gave the highest grain yield at $64 \% \mathrm{Al}$ saturation. In general, at all the Al levels, performances of hybrids were better compared to the lines.

The results are graphically depicted in Figures 2 and 3. In Figure 2, average grain yield at $0 \% \mathrm{Al}$ saturation is plotted against $20 \% \mathrm{Al}$ saturation, whereas in Figure 3 average yield at $0 \% \mathrm{Al}$ saturation is plotted against $40 \% \mathrm{Al}$ saturation. Hybrids in the upper right quadrant show high yield at both low and high Al saturation. Twenty-eight of the 174 hybrids evaluated performed better than the trial average in all three trials $(728039,728047,728107$, 727013, 727029, 727039, 727041, 727079, 727101, 729007, 729015, 729023, 729027, 729029, 729035, 729041, 729045, 729081, 729083, 729087, 729095, 729107, 729109, 0144013, BRS330, AG1020, AG1040, and DKB550). The best check cultivar was the hybrid DKB550, where this hybrid performed very well at all Al saturations. The hybrids AG1020 and AG1040 performed well too; the latter was more tolerant, but the former was more responsive to environment improvement. The hybrid BRS304 (derived from susceptible lines) was classified as susceptible to Al saturation, as it yielded more than $5 \mathrm{t} / \mathrm{ha}$ at low $\mathrm{Al}$, and less than $3 \mathrm{t} / \mathrm{ha}$ at high Al saturation (Figure 3). The three commercial BRS hybrids (BRS310, BRS330 and BRS332) performed better than BRS304 at high Al saturation. The female lines

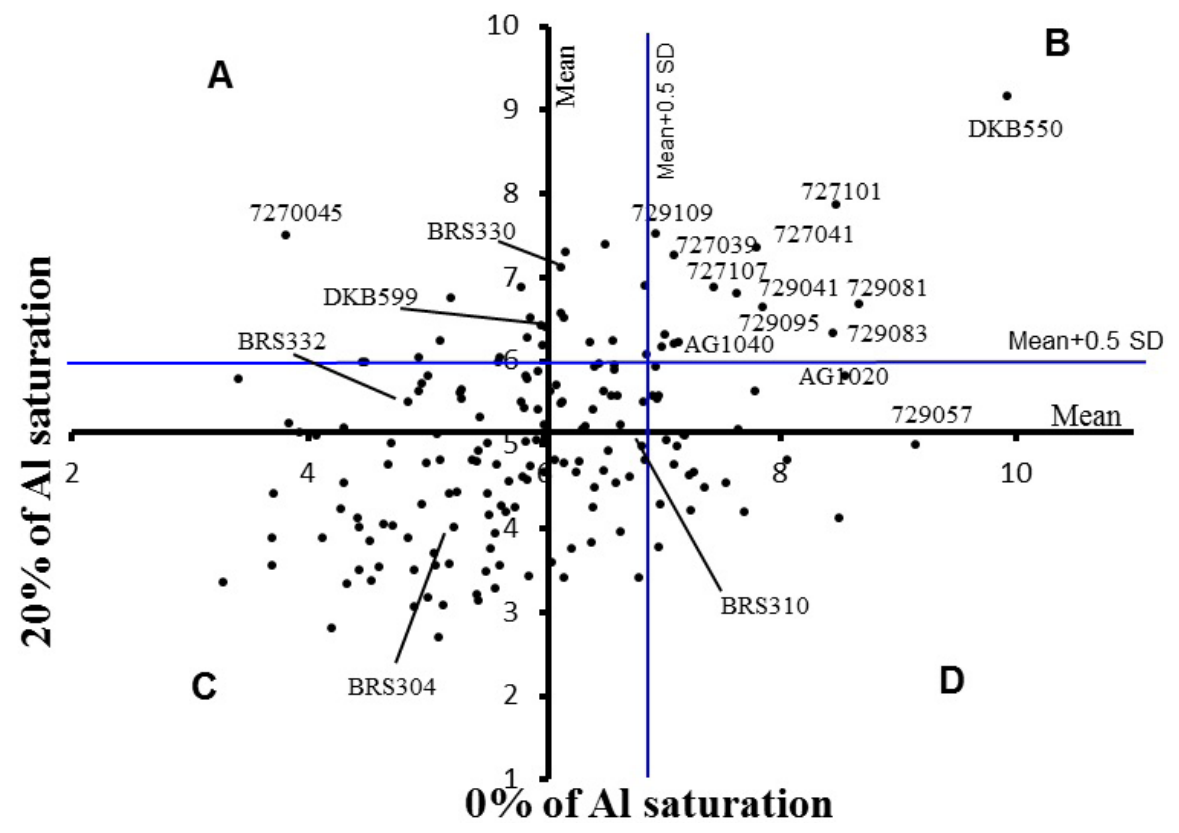

Figure 2. Dispersion diagram of 174 sorghum hybrids at 0 and $20 \%$ of Al saturation for yield. Quadrants: A. identifies genotypes that had low yields at $0 \%$ and high yields at $20 \%$ of Al saturation; B. genotypes with high yields at both levels of $\mathrm{Al}$ saturation; $\mathbf{C}$. genotypes with low yields at both levels of $\mathrm{Al}$ saturation; D. genotypes with low yields at $20 \%$ and high yields at $0 \%$ of Al saturation. Genotypes falling in the region with mean yield over $+0.5 \mathrm{SD}$ (standard deviation) were considered to be tolerant to $\mathrm{Al}$. 
of the hybrids BRS310 (ATF54A) and BRS330 (ATF14A) were tolerant to Al (Schaffert et al., 2009), but the hybrid BRS330 performed much better than BRS310 at high Al saturation, meaning that the male line of the hybrid BRS330 contributed any allele to that performance. This is corroborated by the performance of the hybrid BRS332, which shares the same male line of the hybrid BRS330, but has a susceptible female line (ATF08A) (Schaffert et al., 2009). The performance of BRS332, with yield higher than that of BRS310 at high Al, proved that its male contributed to tolerance to Al. The hybrid DKB559 performed well at high Al saturation, but did not respond to environment improvement.

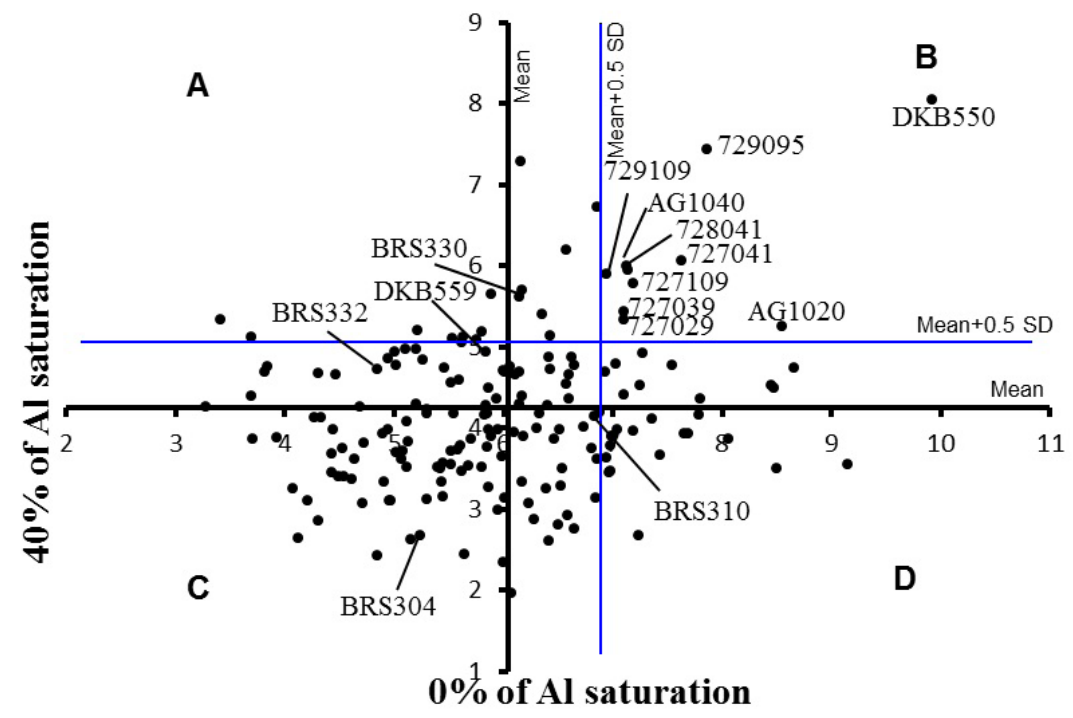

Figure 3. Dispersion diagram of 174 sorghum hybrids at 0 and $40 \%$ of $\mathrm{Al}$ saturation for yield. Quadrants: A. identifies genotypes that had low yields at $0 \%$ and high yields at $40 \%$ of $\mathrm{Al}$ saturation; B. genotypes with high yields at both levels of Al saturation; C. genotypes with low yields at both levels of Al saturation; D. genotypes with low yields at $40 \%$ and high yields at $0 \%$ of Al saturation. Genotypes falling in the region with mean yield over $+0.5 \mathrm{SD}$ (standard deviation) were considered to be tolerant to Al.

On the basis of a selection level of mean yield plus $0.5 \mathrm{SD}, 15$ hybrids $(727029,727039$, 727041, 727063, 727101, 727107, 729023, 729041, 729081, 729083, 729089, 729095, 729109, AG1040, and DKB550) were classified as tolerant and responsive to environment improvement when comparing hybrids at 0 and $20 \% \mathrm{Al}$ saturation (Figure 2).

Considering the same selection level, at 0 and $40 \% \mathrm{Al}$ saturation, 10 hybrids ( 728041 , 727029, 727039, 727109, 729041, 729095, 729109, AG1020, AG1040, and DKB550) were characterized as tolerant and responsive to environment improvement (Figure 3). Seven of these hybrids were classified as having high yield in the three environments $(727029,727039$, 729041, 729095, 729109, AG1040, and DKB550).

Aside from the high yield, new hybrids must have yield stability and adaptability, or particular suitability for the target environments. Studies of adaptability and stability parameters greatly contributed in this respect, by providing information about the behavior of each genotype under different environmental conditions. Using mixed models, Resende (2007a) 
proposed the simultaneous analysis of stability, adaptability and yield on the basis of the harmonic mean of the relative performance of the genotypic values (HMRPGV). Considering the selection for yield and stability, Resende (2007a) described the HMGV method (harmonic mean of genetic values) on the basis of estimates of the harmonic mean of the genotypic values for each genotype tested in different environments. The lower the standard deviation of genotypic performance across environments, the greater is the harmonic mean of its genotypic values. Consequently, the selection of higher values of the harmonic mean results in selection for both yield and stability. For adaptability, a simple and effective measure is the relative performance of genetic values (RPGV) across environments. In this case, the predicted genotypic values are reported as a proportion of the overall mean of each environment, and the average value of this ratio is then calculated for each genotype (Resende, 2007a).

Table 2 presents the RPGVxGM (relative performance of genetic values $\mathrm{x}$ general mean) for the best 28 hybrids, comprising four check cultivars and 24 experimental hybrids. Comparing these hybrids selected on the basis of RPGVxGM with those 28 selected above on the basis of general mean, some differences are observed. Seventeen of those 28 hybrids (61\%) were similar. Among the best 10 hybrids, 4 were check cultivars (DKB550, AG1020, AG1040, and BRS330) and 6 were experimental hybrids.

\begin{tabular}{|c|c|c|c|c|}
\hline Hybrids & $\mathrm{u}+\mathrm{g}^{\mathrm{a}}$ & Confidence range $(\mathrm{u}+\mathrm{g})$ & Phenotypic mean & $\mathrm{PRGVxMG}^{\mathrm{b}}$ \\
\hline DKB550 & 8.052 & $7.492-8.612$ & 9.042 & 8.167 \\
\hline 729095 & 6.156 & $5.377-6.935$ & 7.315 & 6.201 \\
\hline AG1020 & 6.125 & $5.566-6.685$ & 6.543 & 6.160 \\
\hline AG1040 & 6.086 & $5.526-6.645$ & 6.437 & 6.127 \\
\hline 727101 & 6.079 & $5.300-6.859$ & 6.945 & 6.115 \\
\hline 728107 & 6.036 & $5.257-6.815$ & 6.314 & 6.076 \\
\hline BRS330 & 6.033 & $5.474-6.593$ & 6.291 & 6.075 \\
\hline 728047 & 6.012 & $5.233-6.791$ & 6.342 & 6.049 \\
\hline 729081 & 5.886 & $5.107-6.665$ & 6.695 & 5.915 \\
\hline 728041 & 5.884 & $5.105-6.663$ & 6.035 & 5.915 \\
\hline 729041 & 5.850 & $5.071-6.629$ & 6.829 & 5.880 \\
\hline 727039 & 5.809 & $5.030-6.588$ & 6.565 & 5.838 \\
\hline 727041 & 5.784 & $5.005-6.564$ & 6.500 & 5.809 \\
\hline 728027 & 5.740 & $4.961-6.519$ & 5.618 & 5.763 \\
\hline 729109 & 5.732 & $4.953-6.511$ & 6.783 & 5.758 \\
\hline 729083 & 5.705 & $4.926-6.484$ & 6.440 & 5.727 \\
\hline 728057 & 5.660 & $4.881-6.439$ & 5.550 & 5.683 \\
\hline 727029 & 5.657 & $4.878-6.436$ & 6.250 & 5.680 \\
\hline 728039 & 5.599 & $4.820-6.378$ & 5.567 & 5.617 \\
\hline 728033 & 5.568 & $4.789-6.347$ & 5.423 & 5.588 \\
\hline 728081 & 5.517 & $4.738-6.296$ & 5.208 & 5.535 \\
\hline 727103 & 5.509 & $4.730-6.289$ & 6.126 & 5.529 \\
\hline 727107 & 5.482 & $4.703-6.261$ & 5.999 & 5.495 \\
\hline 728059 & 5.476 & $4.697-6.255$ & 5.177 & 5.492 \\
\hline 729023 & 5.442 & $4.663-6.221$ & 6.038 & 5.455 \\
\hline 727025 & 5.436 & $4.657-6.215$ & 5.789 & 5.447 \\
\hline 727109 & 5.420 & $4.641-6.199$ & 6.030 & 5.434 \\
\hline 727083 & 5.412 & $4.633-6.191$ & 5.720 & 5.424 \\
\hline
\end{tabular}

${ }^{\mathrm{a}}$ Genotypic mean or genotypic values. ${ }^{\mathrm{b}}$ Relative performance of genetic values $\mathrm{x}$ general mean.

These 7 hybrids (727029, 727039, 729041, 729095, 729109, AG1040, and DKB550) selected on the basis of mean yield plus 0.5 SD in graphs 0 against $20 \%$, and 0 against $40 \%$ 
were classified among the best 20 hybrids selected based on RPGVxGM, which means that those hybrids are tolerant to Al saturation and responsive to environment improvement and show good stability and adaptability at both low and high Al saturation.

The hybrids starting with 727 have a common male line crossed to different female lines. The same structure can be used for the hybrids starting with 782 and 729. Most of those 28 hybrids selected on the basis of yield average are 729, which did not repeat on selection based on RPGV in relation to the GM.

High Al saturation has a significant effect on hybrid performance in the field and can significantly reduce yield in susceptible hybrids.

\section{CONCLUSIONS}

The hybrids 727029, 727039, 729041, 729095, 729109, AG1040, and DKB550 are tolerant to Al saturation and responsive to environment improvement and show good stability and adaptability at both low and high Al saturation.

\section{ACKNOWLEDGMENTS}

Research supported by the Embrapa Maize and Sorghum, the Research Foundation of the State of Minas Gerais (FAPEMIG), the National Council of Scientific and Technological Development $(\mathrm{CNPq})$, and the Brazilian Federal Agency for Support and Evaluation of Graduate Education (CAPES).

\section{REFERENCES}

Agrianual (2011). Anuário da Agricultura Brasileira. FNP Consultoria, São Paulo.

APPS (Associação Paulista dos Produtores de Sementes e Mudas) (2012). Available at [http://www.apps.agr.br/upload/ de_1009201203221800_area_sorgo_11_12doc.pdf]. Accessed September 20, 2012.

Baligar VC, Dos Santos HL, Pita GVE, Filho EC, et al. (1989). Aluminum effects on growth, grain yield and nutrient use efficiency ratios in sorghum genotypes. Plant Soil 116: 257-264.

Caniato FF, Guimaraes CT, Schaffert RE, Alves VM, et al. (2007). Genetic diversity for aluminum tolerance in sorghum. Theor. Appl. Genet. 114: 863-876.

FAO (2011). FAOSTAT Online Database. Available at [http://faostat.fao.org]. Accessed September 20, 2012.

Flores CI, Clark RB and Gourley LM (1988). Growth and yield traits of sorghum grown on acid soil at varied aluminum saturations. Plant Soil 106: 49-57.

Foy CD, Duncan RR, Waskom RM and Miller DR (1993). Tolerance of sorghum genotypes to an acid, aluminum toxic tatum subsoil. J. Plant Nutr. 16: 97-127.

Hartwig I, Oliveira AC, Carvalho FIF, Bertani I, et al. (2007). Mecanismos associados à tolerância ao alumínio em plantas. Cien. Agrar. 28: 219-228.

Inostroza-Blancheteau C, Soto B, Ulloa P, Aquea F, et al. (2008). Resistance mechanisms of aluminum ( $\mathrm{al}^{13+}$ ) phytotoxicity in cereals: physiological, genetic and molecular bases. J. Soil Sci. Plant Nutr. 8: 57-71.

Kochian LV, Hoekenga OA and Pineros MA (2004). How do crop plants tolerate acid soils? Mechanisms of aluminum tolerance and phosphorous efficiency. Annu. Rev. Plant Biol. 55: 459-493.

Magalhaes JV, Garvin DF, Wang Y, Sorrells ME, et al. (2004). Comparative mapping of a major aluminum tolerance gene in sorghum and other species in the poaceae. Genetics 167: 1905-1914.

Resende MDV (2007a). Matemática e Estatística na Análise de Experimentos e no Melhoramento Genético. Embrapa Florestas, Colombo.

Resende MDV (2007b). Software Selegen - REML/BLUP: Sistema Estatístico e Seleção Genética Computadorizada Via Modelos Lineares Mistos. Embrapa Florestas, Colombo.

Ryan PR, Tyerman SD, Sasaki T, Furuichi T, et al. (2011). The identification of aluminium-resistance genes provides 
opportunities for enhancing crop production on acid soils. J. Exp. Bot. 62: 9-20.

Samac DA and Tesfaye M (2003). Plant improvement for tolerance to aluminum in acid soils - a review. Plant Cell Tissue Organ Cult. 75: 189-207.

Schaffert RE, Silva LA, Alves VMC, Carvalho GA, et al. (2009). The Effect of the AltSB Gene on Root Growth in Nutrient Solution of Isogenic Sorghum Hybrids. 16, 2009. Proceedings of the International Plant Nutrition Colloquium, University of California, Sacramento. 